\title{
VET Again: Now as a VET Teacher
}

\author{
Henriette Duch ${ }^{* 1}$ and Karen E. Andreasen ${ }^{2}$ \\ ${ }^{1}$ VIA University College/Aalborg University, Department of Learning and Philosophy, \\ Krogstrcede 3, 9220 Aalborg, Denmark \\ ${ }^{2}$ Aalborg University, Department of Learning and Philosophy, Kroghstrade 3, 9220 Aalborg, \\ Denmark
}

Received: 14.12.2016; Accepted: 11.05.2017; Published: 22.11.2017

\begin{abstract}
In 2010, a mandatory teacher training course was introduced for new vocational college teachers in Denmark. Since then, all vocational teachers have to complete the same course, regardless of practical work experience and educational background. After completion, they apply the knowledge to a very specific practice (i.e. teaching within a specific vocational field at a specific type of college). Thus, individual teachers experience different 'learning trajectories', depending on the vocational field and place of employment. They amass different experiences, including going back to school, just like newly enrolled students at a vocational college. This paper is based on empirical data from a qualitative study. It examines the learning trajectories of vocational teachers who choose to return to vocational colleges as VET teachers. Based on the analyses of two cases, we discuss the consequences for teachers' pedagogical practice at vocational colleges and its potential for solving various challenges that colleges face.
\end{abstract}

Keywords: VET, Vocational Education and Training, Vocational Teacher, Theory and Practice, Adult Education, Transfer and Transformation, Learning Trajectories

${ }^{*}$ Corresponding author: hedu@via.dk

ISSN: $2197-8646$

http://www.ijrvet.net 


\section{Introduction}

In Denmark all vocational college teachers have both a formal education and years of work experience before they are employed as teachers at the colleges. In addition, newly employed vocational college teachers today are required to take a teacher training course while teaching at the vocational college. One objective of this requirement, which was introduced in 2010 and included in a large reform of the vocational college sector that was passed in 2014, is to counter pedagogic problems and a high student dropout rate.

At Danish vocational colleges, the proportion of students over age 25 has been increasing, and many students have been out of the education system for a number of years before they start on a vocational education. The dropout rate in this group places specific demands on the teachers' pedagogic and didactic competencies and knowledge, and their ability to use these in practice. This includes being able to teach in a way that accommodates and accepts all students regardless of professional level, age, and other factors (Brown \& Katznelson, 2011). With the 2014 reform, slightly different educational programmes were created for young and adult students, and the mandatory pedagogical diploma education was introduced to strengthen vocational college teachers' pedagogical competencies to accommodate students who are returning to the educational system (Government, 2014, p. 2). Just as there is great diversity among the students at VET, the students in at the teacher training course differ considerably in terms of educational backgrounds and work experiences, and especially in terms of their teaching contexts. The article discusses role of the diversity and whether the intentions of the reform and upgrade of the teachers' competencies can be expected to succeed.

Due to the above-mentioned requirements, all teachers at Danish vocational colleges have a biography with experiences from education and, for example, employment in trade and retail, before they start at VET again, now as teachers. In this sense, they are adults returning to VET. All teachers are required to complete a diploma in connection with their teacher training course after they are employed. However, they have different preconditions for developing pedagogically as a teacher and professionally as an employee at a specific college, which is why we talk about different 'trajectories' (Heggen et al., 2015). It is important to look at these conditions because they crucially affect the individual teacher's benefits from the course and how they develop their pedagogical competencies.

European research pays little attention to the importance of vocational college teachers' pedagogical education and its significance for the pedagogy at VET (Misra, 2011). International research on teacher training looks at the educations' standards, access to professions, and economic conditions for students and investigates the relationship between theory and practice in teacher training, which is one of the areas where research indicates a need for improvement (Darling-Hammond \& Lieberman, 2012). Research on vocational college teachers' education points to at least two specific issues: the interplay between theory and practice in the teacher training and the large diversity of teachers who attend the teacher training course (Duch \& Andreasen, 2015).

In education research, the relationship between theory and practice is understood in many different ways (Carr, 1986; Jorgensen, 2005), and in teacher training programmes 
there are many initiatives to qualify this relationship in the education (Laursen, 2015). Some differentiate theoretically between different models for learning in professional educations (Lahn \& Jensen, 2008); others emphasise transfer as an approach (Wahlgren \& Aarkrog, 2012). Teaching in professional educations can thus be conceptualised, explored, and analysed in different ways, which may affect how professionalism is developed. In this article, these issues are thematised via the concept 'trajectories'.

Based on a qualitative study among new teachers at Danish vocational colleges, we investigate the teachers' trajectories and how trajectories, as a consequence of the teachers' pedagogical qualification through the education, can affect the pedagogy and teaching of students at VET. This is a result of the pedagogy that the teachers develop and the considerations about the pedagogy and didactics framed by the activities in the teacher training programme. We are particularly interested in the significance of the teachers' biography and their experiences with attending an education programme about pedagogy at VET, as well as which experiences and knowledge they apply from the education programme for their own teaching at VET.

\section{Becoming a Vocational College Teacher in Denmark}

Vocational college teachers in Denmark must have a vocational education or a professional education in addition to five years' work experience to teach a vocational subject and two years' work experience to teach other subjects (Danish Ministry of Education, 2016). In other words, employed teachers must have both a formal education and be experienced in the vocational area they teach. Once teachers are permanently employed at a vocational college, they must complete a pedagogical course at diploma level within four years. Most teachers choose the Diploma of Vocational Pedagogy, which is a programme in the continuing and further education system (Ministry of Higher Education and Science, 2014). It is level six in the qualification framework and equals 60 ECTS (Ministry of Higher Education and Science, 2016).

The course typically consists of five modules and a final thesis and can be attended full-time or part-time. Most vocational college teachers choose part-time. This means that when someone chooses to become a vocational college teacher, they also choose to study again. The level for the pedagogical education for Danish teachers is at the lower end in Europe. Most teacher training courses are placed at level five to eight in the European Qualification Framework (CEDEFOP, 2016). However, teacher training in Europe is difficult to compare due to varying job requirement and content (Misra, 2011).

In Denmark, the vocational upper secondary education and training (VET) is a dual system. The duration of VET programmes is 3 or 3.5 years, but can vary. The programmes prepare students for a career in trade, industry, or public health service. Teachers employed at technical colleges may have to return to their original education.

The 2014 vocational college reform, which was supported by a broad political majority, mentions vocational college teachers' pedagogical education. In brief, the teachers' pedagogy must contribute to meeting goals stated in the reform: increase the number 
of young people who choose and complete a vocational education; challenge students to take a higher professional level; increase the outside world's confidence in vocational educations (Government et al., 2014).

For example, research shows that a range of inequality issues in vocational education are associated with social inclusion and prestige in society (Jørgensen, 2014). The dropout rate has been a central issue in both education policy and research on vocational colleges (Jørgensen, 2015; Nielsen et al., 2013), and there are different ideas about how to motivate young people at vocational colleges (Nielsen \& Tanggaard, 2015).

In this article, we are concerned with teacher training for vocational college teachers when they return to VET as teachers. We ask about their learning when they move between being students in a course and being teachers at a vocational college together with colleagues and about how experienced similarities and differences in the contexts affect learning.

The article proceeds as follows: We describe the relationship between theoretical and practical knowledge in light of the concept of trajectories. We present our method, empirical evidence, and analytical approach. The analysis focuses on two teachers' learning, and we discuss relationships between contexts that appear to promote learning as well as the trajectories that are indicated in the empirical evidence. Finally, we discuss the possible impact of trajectories on the teachers' pedagogy at vocational colleges.

\section{Theoretical Framework: Trajectories}

Theorists use 'trajectory' to capture development and learning as a process over time in which a person takes part in and experiences different contexts. For example, the sociologist Pierre Bourdieu talks about the concept of habitus and the individual's unpredictable trajectories, or collective trajectories when more individuals have the same objective conditions (Bourdieu, 1992; Yang, 2014). To the anthropologist Jean Lave, trajectories indicate the movement from legitimate peripheral participant to fully-fledged member in a practice community with apprenticeship as the starting point (Lave, 2011; Lave \& Wenger, 2003).

In this article, we apply a more recent approach that originates in socio-cultural theory and empirically considers trajectories within professions in connection with professional educations and practice in workplaces (Heggen et al., 2015), and therefore is particularly relevant here. This theoretical approach integrates different perspectives in the term learning trajectories by including a biographical aspect, educational programme, and use in a profession (Heggen et al., 2015). The approach considers how the individual develops knowledge and habits through socialisation in the education system.

The approach refers to the relationship between context and individual and how this is experienced as "learning trajectories" (Heggen et al., 2015, p. 72). Learning trajectories include different contexts: "competence and expertise are developed over time in a number of different contexts" (Heggen et al., 2015, p. 78). Heggen clarifies coherence in relation to professions: 
"Coherence addresses not only the relationship between different types or dimensions of knowledge but also the interconnections between pieces of knowledge that are developed and used in different contexts, such as pre-enrolment contexts, in-class teaching and placement settings as well as professional work settings." (Heggen et al., 2015, p. 70).

The approach distinguishes between three forms of coherence that all highlight differences in contexts such as "a driving force for learning and professional development" (Heggen et al., 2015, p. 79). The trajectories are formed in collaboration with the biographical, courses, and transformation to a profession, and different forms of coherence can be discussed: biographical, programme, and transitional coherence. Biographical coherence is about meaningful connections to previous knowledge and experiences. Programme coherence "focuses on how students experience the relationships amongst the different elements of the curriculum and on the connections between in-class education and placement experience" (Heggen et al., 2015 p. 80). Transitional coherence "examines the relationship between knowledge and skills acquired in professional education and the actual work carried out by newly qualified professionals" (Heggen et al., 2015, p. 82). Transitional coherence is both about learning in the transformation from education to the workplace and continued learning and development.

Heggen and Smeby ask "is coherence an unequivocal good, and is it certain that the most possible connection also give the best professional qualification?" (Heggen \& Smeby, 2012, p. 10) 1 Their answer is that it is possible to go too far in the desire for coherence because we are dealing with different forms of knowledge. They differentiate between consistency and coherence, where consistency is a connection free from contrast. They do not view consistency as appropriate since contrasts are an educational motivation, and since professions are in continuous development, contrasts are a part of the changeableness. "Coherence must therefore not be about giving the impression of simple connections, but that the real contrasts become exposed so that they can be evaluated" (Heggen \& Smeby, 2012, p. 12) 2

Our starting point is empirical, based on the assumption that vocational college teachers, who have had both life and work experience, continue to learn on the basis of their biography. A VET-educated individual who returns as a VET teacher and is required to attend the teacher training course, enters specific physical and social connections at a vocational college as teacher and a dynamic exchange between a course with a curriculum, teaching, preparation, and examination tasks. In both contexts, there are social relationships with colleagues and fellow students, and the students shift between the two contexts over a number of years. We use the concept of trajectories in relation to how the vocational college teachers describe their learning through the course connected to a biographical perspective and the transformation to the vocational college.

Our analytical approach thus relates to biography, education, and transition, and we examine how the teachers in the interviews relate to questions about coherence and how contrasts and similarities in contexts affect learning, cf. trajectories.

\footnotetext{
${ }^{1}$ Our translation.

${ }^{2}$ Our translation.
} 


\section{Method}

The article builds on qualitative data on vocational college teachers who are enrolled in the Diploma of Vocational Pedagogy. The data was collected in 2014-2017 as part of a longitudinal research project on teachers' social and academic development as students in the course $3^{3} 20$ teachers participated from four different Danish vocational colleges: a technical college, a business college, a social and health college, and a combined business and technical college. The teachers analysed in the two cases are selected on the basis of a principle of variance (Yin, 2014), i.e., educational background and experience, branches and place of employment - they teach at two different colleges - and for instance how they are integrated in the community of teachers at their college. They represent the diversity among the students in the course and can thus clarify the different trajectories and differences concerning the return to VET.

Data was gathered in focus group interviews conducted in the spring and autumn of 2015, focus group interviews with managers at each college in autumn 2014 (Barbour, 2007), and documents were collected that describe each vocational college's organisation and structure for the teacher training course, i.e., the management's practice and intentions that influence the teachers' trajectories. Eventually, as the teachers finish the course, their final theses are collected, and the teachers are interviewed.

The teachers have different trajectories. We specifically asked about their use of the course in vocational college teaching and more generally what they learned in the course. We show this difference in the analysis of the two cases, Ole and Kit 4 The interviews were transcribed and quotations revised linguistically with a view to readability (Bloor, 2001).

First, data on trajectories for the two cases was selected. The data shows that the teachers' teaching at VET changes, and that they gain something from the course. Afterwards, the data is analysed and categorised as primarily biographical, i.e., background or changes outside the course or vocational college; aspects regarding content from an educational programme or being in an educational programme; and concerning the transition regarding which parts of the course the informants reflect, so that it can be a part of the pedagogical work at the vocational college.

\section{Analysis}

As mentioned, the two cases illustrate that the return to VET as a teacher may involve very different trajectories with different forms of coherence. The data shows that this is challenging but that the individual teacher copes.

The analysis is divided into three sections with reference to the themes mentioned in the theory section: biographical, programme and transition. The first section concerns biographical coherence when the teacher returns to VET as a teacher. In the programme or course section, we look at the teachers' description of the course curriculum from the

\footnotetext{
${ }^{3}$ Data is collected by Henriette Duch.

${ }^{4}$ The names are pseudonyms.
} 
in the form of attention to the students' learning and the concept of motivation, which both teachers talk about but modify for their own context. The last section are about transition and includes specific examples of transition based on how the teachers adjusts their teaching in the context of vocational colleges and thus change VET.

In short, the case about Kit describes a business college-educated woman who has chosen a vocational education rather than a higher education and basically does not wish to take the higher education programme, which a Diploma of Vocational Pedagogy is, since she believes that she is good at teaching. During the course, however, she discovers new perspectives that give rise to new approaches to teaching. Ole is employed at the technical college and does not have the same resistance to the educational programme; however, he is less familiar with attending courses and is more isolated at the employing college in terms of renewing its pedagogy.

\subsection{Back to VET}

This first section is about biographical coherence. Ole is in his mid-30s when he, encouraged by his previous teacher, returns as a teacher at the technical college where he was educated. He has worked professionally for nearly 20 years and explains the job change with the effects of hard, physical work and a desire for more open working hours. Ole did not prioritise secondary school when he was young, and being newly employed at the vocational college, he takes the subject 'Danish' at college to improve his reading skills before he starts on the teacher training course. He says that the teaching training course is of more than just professional importance. It is important for his relations in his family and for him as a citizen, because he is also developing his ICT skills. In addition, the pedagogy course challenges him in ways that he will miss when he is done. He has been a part-time student for three years in the Diploma of Vocational Pedagogy:

As a newly employed teacher, he immediately starts teaching at the workshop, but he follows a colleague's teaching in the theory class. "I organised workshops on my own, and then I listened when he ran theory (...). In short, I was thrown to the lions from the first day" (Interview). Later, he receives advice about teaching from a colleague in another department.

Kit is in her mid-30s, graduated from a business college, and is returning as a business college teacher after 10 years' work experience, where she has been responsible for personnel, purchasing, teaching in-house courses and has taken a higher postgraduate course. She had more than five years' teaching experience at the vocational college when she was asked about starting the pedagogy course:

"Previously, I just went in and taught and thought that I was absolutely right about what I did (...). I was of course not a believer in having to do the Diploma of Vocational Pedagogy; on the contrary, I sat there and was almost crying before I had to go and didn't want to go at all." (Focus group interview)

She explains that she was against the course because she did not want to take a higher education; if she did, she would have chosen it herself. Instead, she wants to be with her pupils at the college. 
When she finishes the course after three years as a part-time student, she has a new function at the vocational college, namely to work closely with local businesses and pupils to establish internships. In this sense, she uses her work experience in an entirely new way. Ole talks excitedly about potential new vocational challenges at the college, and in this sense there are also new possibilities in the relationship between being a teacher and the vocation that he comes from.

\section{The Trajectories}

Based on the above, one can conceptually say that Ole describes a trajectory characterised by a connection between the biographical starting point, the course, and the transition to the profession as a teacher. He chooses the job as a vocational college teacher because he is physically worn down and due to his working conditions, and what he learns during the course influences his private life too. The course confirms his intuitive pedagogical choices as a new vocational college teacher, and in this way, there is a connection, just as he sees new professional challenges that link to his previous occupation. Ole highlights connections between experiences and tasks in different contexts. In this way there is coherence between pre-enrolment contexts, the course and his function as a vocational college teacher.

Kit's trajectory is different in the sense that she first notices differences between theoretical courses, which she has deliberately not chosen, and being a teacher at a vocational college. Her new job functions are an extension of her previous work experiences and thus a connection across the different contexts emerges. Kit reflects on trajectories characterised by differences, but connections reveal themselves over time and coherence occurs. Based on the two cases, it can be said that a biographical connection across contexts is found over time, even though one of the cases illustrates expectations that disagreements and differences between contexts can create problems in the short run.

\subsection{Trajectories on the Course}

This section is about the course and how it connects with biography to make coherence. Kit experiences the concepts in the course as foreign, but eventually the Diploma of Vocational Pedagogy makes sense to her, and the examination assignments establish a connection between the teaching job and the pedagogical course.

"In some of the first modules, I was about to get grey hair: what kinds of words are these, I don't know them, and what should I use them for? I then begin to do the assignments, and it becomes more practice-based, then I can really see the connection, and then it also starts to make sense to me." (Interview)

In particular, theory of science makes Kit aware of her position as a teacher; it enables her think about her subject and teach in new ways. Kit and Ole experience coherence between biography and their expectations and experiences in the course in each their way. Ole does not mention resistance and lack of connection as Kit. Instead, he talks about being confirmed: 
"I think that it was nice, when you just get out of the former job and get thrown into a class and have to teach, you of course don't have any teaching experience, and then get confirmed that some of what you have done was in fact correct seen from a didactic point of view (...) You breathe a little easier. It was great to put some concepts on it." (Focus group interview)

Kit reflects on her formal relationship to the teacher in the course and supervision in regard to passing examinations:

Kit: [I have had] supervision meetings where I have shown her what I have done, and then she said whether I was on the right track or not.

Interviewer: What does it mean to be on the right track?

Kit: It means a lot, because then you really know.

Interviewer: What is it you want to know when you ask if you are on the right track?

Kit: Yes, well, that I'm not going to fail of course. That is really the main goal.

Kit says that she has not evaluated her work herself by looking at the courses' learning goals, and she says that she has learnt most from the final thesis of 15 ECTS point: "I think I have learnt the most from the final thesis." (Interview)

Ole thinks that he has developed as a person during the course by meeting new people:

"That's what I think develops you personally, that you get to meet new people.

If you are open to some of the things they come with, and you yourself are

stuck in the same groove, then of course you'll learn something." (Interview)

Ole has kept in e-mail contact with two teachers from other colleges, even though they are not always in the same class on the course. We identify two points: He finds a community in the course that he does not have at VET (see below), and he establishes continuity in a modularised course through personal relationships that he occasionally makes use of when he is preparing examination.

Summing up, Kit and Ole experience assessments and examinations in different ways. Kit's goal is to pass the course, so the course itself is important and maybe isolated and less important for the job as a teacher even as she has found a more practically oriented coherence. To Ole the relation between the course and his personal development is important, and he seems to be connecting to a biographical dimension. The interpersonal relationships to other students as well as the confirmation also belong to this dimension.

\section{The Content of the Course}

This part of the section focuses on the relation between biography and the content of the course. The course includes a pedagogical conceptual framework, which is new to the teachers. Both teachers talk about their pupils' learning and motivation as elements from the course, but they talk about them in different ways. 
Ole highlights that he has become aware that the pupils' learning is the most important part of the course. He works with "creating a motivated learning space for them, among other things by "including some ICT"' and being empathic. He says,

"I try to be empathic in my approach, be understanding and not judgemental. I hope that it will give them a good educational experience".

If the students are passive, he talks to them, if necessary in collaboration with a pupil coach, to find the reasons: "Of course, there is a reason that the pupil is not active in class". Ole refers to Bandura, whom he has studied during the course, in relation to not being judgemental of pupils.

Kit does not talk explicitly about teaching but rather about pupil prerequisites and motivation. She thinks that motivation is a recurring issue in all the course modules, "It is also very much what the modules are about. How do you best plan the programme for your pupils so that they are motivated in the classroom? Motivation is a word that almost fills all the modules." (Focus group interview)

One can ask why they notice different elements from the course. All classes have the same learning goals and presumably similar content. A possible answer can be found in the relationship between the biographical and the course. Kit has chosen to teach because of interaction with pupils. She makes a connection between good teaching programmes and motivation; in other words, if the teacher plans well enough, the pupils become motivated. Motivation therefore becomes the key to teaching.

As mentioned, Ole had another reason to become a teacher. He has subsequently become aware of the pupils through his work at the vocational college and through the course, so now the pupils' learning is central for him. He connects learning space, ICT, empathy, motivation, and Bandura, but without expanding on the theory of selfefficacy, which is often included in the course. Ole does not elaborate on how these things are connected, but for the purpose of this article the point is that he sees a connection between the different contexts. Like Kit, he has constructed a connection between something that is motivating for him: the pupils, content, and concepts from the course and the teaching job.

Our point is that Kit's and Ole's biographies might explain why their understanding of the content of the course differs.

\subsection{Trajectories at VET: Organisational Models, Colleagues and Changing Teaching at the Vocational College}

This section is about the transition from course to VET, first in connection with the management's initiatives and ideas on organisationally connecting the Diploma of Vocational Pedagogy and VET, and afterwards in relation to Ole's and Kit's cooperation with colleagues at VET.

The four vocational colleges in the overall study have different initiatives and ideas about how best to support the teachers' pedagogical education programme and get them to develop the pedagogy and college culture as the individual college would like. At the college where Kit is employed, VET teachers are supported with internal supervision on assignments for the course as a supplement to the supervision during the course, but the 
long-term plan is that VET teachers with a Diploma of Vocational Pedagogy can be part of implementing the pedagogical and didactic foundation the management has defined. At the college where Ole is employed, new teachers are supported with basic teaching theory and individual supervision before they start the course, and VET teachers are taught A-level subjects such as Danish before the course. In the long term, teachers with a Diploma of Vocational Pedagogy are seen as frontrunners for college development. At a third college, VET teachers attending the course are integrated in committees and development work, and the management works to become acquainted with the professional content in the course. The long-term goal is to exploit the potential for college development in contrast to a fourth college where the management establishes control mechanisms to develop teaching. The objective is specific action rather than overall reflections by the teachers. The specific college contexts in which Ole and Kit find themselves offer organisational possibilities for trajectories that would look different if they returned to VET at another college. According to the theoretical framework, the organisational context is forming learning trajectories.

\section{The Colleagues at VET}

Vocational college teachers typically have colleagues who come from the same or related vocations. However, for Ole there is a contrast between the vocational aspect that colleagues respect and the pedagogical aspect: "I don't think that there is support from colleagues (...) One of the things I kept hearing when I started was statements like, 'Great that we don't have to do that [the course]. Wow, that's a waste of resources'" (Focus group interview).

Ole did not experience support from colleagues to renew the teaching: "There's no support in our team to do new things. There is a battle (...) against new ways of teaching" (Focus group interview).

One would think that such statements about the course and renewal of teaching would decrease the interest in the pedagogical aspect, but this is not present in the data. Ole exposes contrasts between the course and possibilities at the workplace, but he continues to work with new initiatives. It appears that he sees connections between the course and the workplace, even though there is a big difference between colleagues' opinion of pedagogy and what he learns in the course. We cannot say whether the difference between the contexts requires learning, but Ole indicates that he is continuing with his renewal. In contrast, Kit collaborates with her colleagues. She says that a colleague asked about her final thesis and borrowed her assignment. At the vocational college, those who are attending the course share notes and assignments. "I think we are really good at sharing. We have a shared drive where we put all of our things, that is, examination assignments and notes" (Interview).

In contrast to Ole, Kit does not talk about pedagogical supervision before the course but about colleague supervision in connection with her final thesis, "to correct my spelling mistakes (...) he has also been good to talk to about theory: 'Okay, you say (...) this theory of science, you have to write who says something about it"" (Interview).

Kit thus has collegial collaboration on preparation of the curriculum in the form of notes and in relation to internal supervision of examination assignments. On this basis, 
we assume that transition of knowledge from the diploma to the workplace must be easier for Kit than for Ole, but we cannot know whether the two, due to the different opportunities for collaboration, change the pedagogy at the vocational colleges to different extents or in different ways. What we know is that the conditions for collegial cooperation differ and this becomes a part of the context as a condition for coherence.

\section{Changes of Teaching}

Ole says that he is the only one who attempts to organise the special tools in the workshop at the college:

"The tools are thrown in the cupboard. You weren't able to see whether the tools were there, and how many of them there were. If something was missing, you didn't know about it before someone needed it. Now, there is a cupboard with pictures, where it's written what kind of a tool should hang there, so now it takes 10 seconds to get an overview. It has taken a long time to do, but the others can clearly see that it's good." (Interview)

He has also scanned the technical manuals so that the pupils can get them digitally. He uses ICT to introduce new working and learning methods in the teaching. Pupils with writing difficulties can work with sounds and pictures rather than with writing alone. In this way, he works with differentiation and individual learning.

Thus, Ole reports on some specific initiatives at VET. The organisation of tools can both be about good practice in the vocation that he comes from, which the pupils must learn, and it can be about the teacher having an overview of materials and tools in teaching situations. Similarly, access to manuals can both be about how to work in the vocation and about qualifying teaching and the pupils' learning, while ICT is directly about learning at VET. The examples show that Ole connects his work experience and teaching at VET, and that he connects the use of and understanding of ICT in relation to being a citizen in a digital society rather than only being about technology in a vocation. In doing so, he connects his biography, the course, and the transition to pedagogy at a vocational college. On the basis of our theoretical starting point, it can be said that these three things and the different contexts are in a complex relationship with each other, so the main point here is that a connection is created.

Kit also works with ICT by qualifying the use of electronic books at the vocational college, and she has become aware of how complex it is to teach the pupils vocational use of a new medium, even though young people are often called 'digital natives'. In economics subjects, she has worked with visualisation of concepts such as VAT and tax. The pupils prepare posters that she continuously returns to, which is also a way to differentiate and involve the individual pupil's learning. She says: "I do not just focus on the content, because then I don't get the best out of my pupils." (Focus group interview)

Kit argues that pupils are her starting point and visualisation allows her to embed abstract vocational concepts in the pupils' everyday understanding and ensure continuity by returning to the posters. Through theory of science, she has discovered that she can choose other approaches to teaching in spite of a very specific vocational content. As was the case for Ole, a complex relationship between her own vocation, the course's new 
perspectives, and her teaching on VET can be seen. This raises a fundamental question of whether it would have been possible for her to work with the visual approach in her teaching without a course that changes a perhaps biographically rooted understanding of the vocation. We do not believe it would, so the course has importance for a renewed view of VET's opportunities when the teacher returns to VET.

The analyses indicate three things. First, the cases show different organisational contexts concerning the management of the Diploma of Vocational Pedagogy and collegial cooperation. Second, the variation in contexts sets a framework for the practice at the vocational college and thereby for the learning trajectories. Third, the cases indicate renewal of the teaching at VET, but it is closely connected to biography and Diploma of Vocational Pedagogy.

\section{Conclusion and Discussion}

The analysis shows that the teachers' biographies have an impact when they return to VET, both in relation to their motivation for the course and in relation to finding meaning in the course. It challenges their views of the pedagogical possibilities in VET, which appear to be a motivating force in their teaching that wins over Kit's resistance and makes Ole seek new challenges. Connections are created across different contexts: one in relation to the Diploma of Vocational Pedagogy's curriculum and the meeting with other VET teachers at the course; one in relation to the college models and collaboration opportunities with colleagues at VET; and one in relation to development of VET and very diverse, specific initiatives.

The fact that the two teachers move between different contexts does not prevent learning, but does it improve learning? We can say that the argument that a connection between theory and practice depends on great similarities or recognisable elements is not a condition in the cases. On the contrary, complicated relationships and connections between the biographical, the course, and teaching at VET create learning in ways that could not have been predicted, either as a need in VET or as an opportunity for the individual teacher.

The analysis causes us to consider whether there is an opportunity in the course to didactically 'design' other trajectories and whether there is an opportunity in the course and at the individual vocational college to support the individual teacher's learning, even though organisational models, collegial resistance or collaboration do not appear to ensure or prevent transition.

Even though we have not specifically asked about the relationship with the teachers' vocational education, it appears that it is the biographical starting point from where they are speaking, and that both, because of new (potential) tasks at the vocational college, maintain relationships with the vocation as a teacher. Ole makes a distinction between teaching theory and teaching in the workshops, where the challenge as a new teacher is described in particular relation to the former. However, it cannot be said that the Diploma of Vocational Pedagogy is used differently in the two types of teaching, but Ole's renewal of the vocational college concerns organisation of tools and pupils' 
access to teaching aids in addition to pedagogical initiatives in learning, motivation, and differentiation. Kit learns from theory of science that she can approach her vocational subject and thus teaching in other ways, including work with motivation, visualisation, and electronic teaching aids.

The teachers' pedagogical development is therefore linked to different trajectories that reveal themselves in the field between the biographical, the course, and VET, also when the contexts differ. The two cases show that coherence can certainly arise without homogeneity, but on the basis of heterogeneity when teachers return to vocational college. Finally, we will discuss whether, through such trajectories, a sort of loss in relation to the teachers' vocationalism can occur. In other words, does the course take the teachers to another place than the vocational college. On the one hand, the analysis shows that the trajectory continues to be rooted in the vocation, but while Ole's colleagues emphasise that vocational courses are more important than a Diploma of Vocational Pedagogy, they do not, according to Ole, exercise traditional craftsman virtues such as keeping the tools in order, teaching the pupils to do it, and ensuring electronic access to manuals. Ole works with these tasks, which are closely connected with the vocation, based on the pedagogical approaches he encounters in the course. It appears that the course affects the ability to work pedagogically with knowledge from the branch as a teacher at VET.

We may ask whether Kit and Ole become more theoretical because of an education at level six in the qualification framework, but the data suggests that they transform the curriculum from the course to teaching at their vocational colleges and thus the particular learning context. Their references to the curriculum are specific when Bandura is mentioned, while the concepts of learning and motivation, which are used in the cases, appear to be understood very broadly. In this sense, the teachers modify the knowledge from the course to VET and the local need for pedagogical development. On a general level, the analysis raises the question of how, in a curriculum or in a vocational college as an organisation, one would be able to take account of what is needed pedagogically in the specific context at VET, and which relations and collaboration opportunities support the individual's trajectories. Our answer is that it requires knowledge of the individual VET teacher's biography and contexts. However, we do not doubt that the teachers' newly acquired experiences being in a course affect how they pedagogically meet and understand pupils at VET who in a similar way are enrolled in courses. 


\section{References}

Barbour, R. S. (2007). Doing focus groups. Los Angeles, Calif.; London: SAGE.

Bloor, M. (2001). Focus groups in social research. London: Sage Publications.

Bourdieu, P. (1992). Outline of a theory of practice. Cambridge: Cambridge University Press.

Brown, R. \& Katznelson, N. (2011). Motivation i erhvervsuddannelserne. Med eleverne ind i undervisningsrummet til faget, pædagogikken, lærerne og praktikpladsmanglen. [Motivation in VET] Anden delrapport. Center for Ungdomsforskning, DPU, Aarhus Universitet.

CEDEFOP, (2016). Briefing note - Professional development for VET teachers and trainers. Retrieved 4 August 2016, from: http://www.cedefop.europa.eu/en/publi cations-and-resources/publications/9112

Carr, W. (1986). Theories of Theory and Practice. Journal of philosophy of education 2, 20., p. 177--186.

Danish Ministry of Education (2016). Bekendtgørelse om erhvervsuddannelser. Bek nr 367 af 19/04/2016 [Law of Vocational Educations). Retrieved 25 august 2017, from: https://www.retsinformation.dk/Forms/R0710.aspx?id=179825

Darling-Hammond, L., \& Lieberman, A. (2012). Teacher education around the world. What can we learn from international practice. In L. Darling-Hammond \& A. Lieberman (Red.), Teacher education around the world: changing policies and practices. Abingdon: Routledge.

Duch, H., \& Andreasen, K., E. (2015). Reforming Vocational Didactics by Implementing a New VET Teacher Education in Denmark: Tensions and Challenges Reflected in Interviews with Vocational College Teachers, International Journal for Research in Vocational Education and Training, 2(3), 195-213.

Government [Regeringen et al.] (2014). Aftale om Bedre og mere attraktive erhvervsuddannelser. Aftaletekst mellem Regeringen (Socialdemokraterne og Radikale Venstre), Venstre, Dansk Folkeparti, Socialistisk Folkeparti, Konservative Folkeparti og Liberal Alliance. 22 February. [Political agreement about Better and more attractive VET)].

Heggen, K., \& Smeby, J.-C. (2012). Gir mest mulig samanheng også den beste profesjonsutdanninga? [Does maximum similarities give the best vocational education?] $n r$ 01 Norsk pedagogisk tidsskrift.

Heggen, K., Smeby, J.-C., \& Vågan, A. (2015). Coherence: A longitudinal approach. In: Smeby, J.-G. \& Suthpen, M. (ed.). From Vocational to Professional Education: Educating for Social Welfare. Routledge Research in Higher Education.

Jorgensen, E. R. (2005). Four philosophical models of the relation between theory and practice. 13, 1 Philosophy of Music Education Review, 21-36.

Jørgensen, C. H. (2014). The current state of the challenges for VET in Denmark. Roskilde University Department of Psychology and Educational Studies, Nord-VET - The future of VET in the Nordic Countries.

Jørgensen, C. H. (2015). Shifting problems and shifting policies to reduce student dropout - the case of vocational education policy in Denmark. In Bohlinger, S.; Dang, 
K. A., \& Klatt, G. (ed.), Education Policy. Peter Lang.

Lahn, L. C., \& Jensen, K. (2008). Profesjon og læring. [Profession and learning]. In A. Molander \& L. I. Terum (Red.). Profesjonsstudie. Oslo: Universitetsforlaget.

Laursen, P. F. (2015). Multiple bridges between theory and practice. I Smeby, J.-C. \& Sutphen, M. (Red.), From Vocational to Professional Education. Routledge.

Lave, J. (2011). Apprenticeship in critical ethnographic practice. Chicago: University of Chicago Press.

Lave, J., \& Wenger, E. (2003). Situeret læring. I Situeret laring - og andre tekster [Situated learning — and other texts]. København: Hans Reitzel.

Ministry of Higher Education and Science [Uddannelses- og forskningsministeriet] (2014). Bekendtgørelse af lov om erhvervsrettet grunduddannelse og videregående uddannelse (videreuddannelsessystemet) for voksne, LBK nr 578 af 01/06 /2014. [Statutes about further education].

Ministry of Higher Education and Science [Uddannelses- og Forskningsministeriet] (2016). Kvalifikationsrammen for Livslang Læring. [Qualifications Framework for Lifelong Learning]. Retrieved 22 September 2016, from: http://ufm.dk/uddannelse-og-instit utioner/anerkendelse-og-dokumentation/dokumentation/kvalifikationsrammer/kvali fikationsrammen-for-livslang-laering\#cookieoptin

Misra, P. K. (2011). VET teachers in Europe: policies, practices and challenges. Journal of Vocational Education \& Training, 63(1), 27-45. https://doi.org/10.1080/136368 20.2011 .552732

Nielsen, K., Jørgensen, C. H., Koudahl, P.;,Munk, M., Pilegaard, T., Tanggaard, L. (2013). Slutrapport: Erhvervsskoleelever i det danske erhvervsuddannelsessystem. Aarhus. [Final report: Pupils in the Danish VET] Retrieved 12. December, 2016 from: http://psy.au.dk/fileadmin/Psykologi/Forskning/Forskningsprojekter/Fastho ldelse_af_erhvervsskoleelever/Slutrapport28082013final.pdf

Nielsen, K., \& Tanggaard, L. (2015). Dropping out and a crisis of trust. Nordic Psychology, 67(2), 154-167. https://doi.org/10.1080/19012276.2015.1028763

Wahlgren, B., \& Aarkrog, V. (2012). Transfer: kompetence $i$ en professionel sammenhæng. [Transfer. Competences in professional contexts] Aarhus: Aarhus Universitetsforlag.

Yang, Y. (2014). Bourdieu, Practice and Change: Beyond the criticism of determinism. Educational Philosophy and Theory, 46(14), 1522-1540. https://doi.org/10.1080/ 00131857.2013 .839375

Yin, R. K. (2014). Case Study Research: design and methods. Thousand Oaks, Calif.; Los Angeles: Sage. 


\section{Bibliographical Notes}

Dr Henriette Duch is an associate professor at VIA University College and $\mathrm{PhD}$ student at Aalborg University, Department of Learning and Philosophy, Denmark. Her research interests are vocational pedagogy, vocational teacher education, adult education and professionalism.

Dr Karen E. Andreasen is associate professor at the Aalborg University, Department of Learning and Philosophy, Denmark. Her research interests are learning in educational settings, vocational education and pedagogy. 